\title{
STUDI PERENCANAAN TPA MASUKAU DENGAN SISTEM SANITARY LANDFILLDI KABUPATEN TABALONG KALIMANTAN SELATAN
}

\author{
Rahmat Nazhary ${ }^{1}$, Warih $K^{2}$ \\ ${ }^{1}$ Dinas Pekerjaan Umum Kabupaten Malang \\ ${ }^{2}$ Jurusan Teknik Sipil Fakultas Teknik - Universitas Muhammadiyah Malang
}

\begin{abstract}
Open dumping is one method of waste management is cheap and easy to do the operation. This method has many shortcomings, because the leachate produced can not be controlled, odor, poor aesthetics, pollution of ground and surface water, as well as other negative effects. However, this method is used throughout the existing landfill in Tabalong, where no management / pollution prevention good to excellent water, air, and soil, as well as the control of environmental sanitation. Need a change in the method of open dumping of waste management into a Sanitary Landfill in accordance with Law no.18 of 2008 on waste management. sanitary landfill system is one of the waste management system controlled by good sanitation system. Waste is disposed of at the End Processing (TPA), then garbage compacted with bulldozers and then closed ground. From the results of the analysis, a population of 2032 as many as 5,394,643 souls and waste generation amounted to $668,760.08 \mathrm{m3}$. From the slope stability analysis obtained by using the value of FS Bishop $=4.322$, Fellenius $=4.019$, and the method is declared safe Janbu $=3.814$.
\end{abstract}

Keywords: Sanitary Landfill, slope stability, Methane Gas.

\begin{abstract}
Abstrak
Open Dumping merupakan salah satu metode pengelolaan sampah yang murah dan mudah untuk dilakukan pada pengoperasiannya. Metode ini memiliki banyak kekurangan, karena lindi yang dihasilkan tidak dapat dikontrol, menimbulkan bau, estetika yang buruk, pencemaran air tanah dan permukaan, serta dampak negatif lainnya. Namun metode inilah yang digunakan di seluruh TPA yang ada di Kabupaten Tabalong, dimana tidak ada pengelolaan/pencegahan yang baik terhadap pencemaran baik air, udara, dan tanah, serta control terhadap sanitasi lingkungan. Perlu adanya perubahan metode pengelolaan sampah dari Open Dumping menjadi Sanitary Landfill sesuai UU no. 18 tahun 2008 tentang pengelolaan sampah. sistem sanitary landfill ini merupakan salah satu sistem pengolahan sampah terkontrol dengan sistem sanitasi yang baik. Sampah dibuang ke Tempat Pemprosesan Akhir (TPA), kemudian sampah dipadatkan dengan bulldozer dan selanjutnya di tutup tanah. Dari hasil analisa diperoleh jumlah penduduk tahun 2032 sebanyak 5.394.643 jiwa dan timbulan sampah sebesar $668.760,08 \mathrm{~m} 3$. Dari analisa stabilitas lereng didapat nilai FS dengan menggunakan metode Bishop $=$ 4,322 , Fellenius $=4,019$, dan metode $\mathrm{Janbu}=3,814$ dinyatakan aman.
\end{abstract}

Kata Kunci : Sanitary Landfill, Stabilitas Lereng, Gas Metan.

\section{PENDAHULUAN}

Masalah pembuangan sampah merupakan salah satu isu utama bagi setiap kota di indonesia. Jumlah atau volume sampah sebanding dengan tingkat konsumsi terhadap barang/material yang digunakan sehari-hari. Keberadaan volume sampah yang semakin hari semakin bertambah besar dapat mencemari tanah, air dan udara, sehingga dapat mengganggu kesehatan dan kenyamanan masyarakat sekitar.
Tchobanoglous, Theisen, dan Vigil (1993) mengatakan, salah satu metode yang dikenal dalam pembuangan sampah adalah Open Dumping. Metode ini murah dan mudah untuk dilakukan pada pengoperasiannya, namun metode ini memiliki banyak kekurangan karena lindi yang dihasilkan tidak dapat dikontrol, menimbulkan bau, estetika yang buruk, pencemaran air tanah dan permukaan, serta dampak negative lain. Namun metode inilah yang digunakan di seluruh TPA yang ada di Kabupaten Tabalong, dimana tidak ada pengelolaan/pencegahan yang baik terhadap pencemaran baik air, udara, dan 
tanah, serta control terhadap sanitasi lingkungan. Hal ini yang melatar belakangi Studi Perencanaan Tempat Pengolahan Akhir (TPA) Masukau yang sesuai dengan UU no 18 tahun 2008 tentang pengelolaan sampah yaitu dengan menggunakan sistem sanitary landfilll.

\section{Permasalahan}

Meningkatnya jumlah penduduk di Kab. Tabalong mengakibatkan peningkatan volume sampah yang mana jika tidak dikelola dengan baik akan menimbulkan dampak negative bagi lingkungan. Belum adanya TPA yang menerapkan metode sanitary landfill untuk TPA di Kab.Tabalong.

\section{METODE PENELITIAN}

\section{Kondisi Umum Wilayah Studi}

Secara umum Kabupaten Tabalong terletak di antara $1,18^{\circ} \mathrm{LS}-2,25^{\circ} \mathrm{LS}$ dan $115,9^{\circ} \mathrm{BT}-115,47^{\circ}$
BT, dengan Kota Tanjung sebagai ibukota daerah Kabupaten Tabalong. Secara administrasi Kabupaten Tabalong dibatasi oleh wilayah-wilayah sebagai berikut:

- Sebelah Utara : Provinsi Kalimantan Timur

- Sebelah Barat : Provinsi Kalimantan Tengah

- Sebelah Selatan : Kabupaten HSU dan Kabupaten Balangan

- Sebelah Timur : Kabupaten Balangan dan Prov. Kalimantan Timur

Kabupaten Tabalong terletak paling utara dari Provinsi Kalimantan Selatan, dengan luas wilayah $3.946 \mathrm{~km}^{2}$ atau sebesar 10,61\% dari luas Provinsi Kalimantan Selatan. Perencanaan konstruksi TPA Masukau ini terletak di desa Masukau Kecamatan Murung Pudak Kabupaten Tabalong. Dengan luas area lahan untuk TPA Sanitary Landfill yang telah disiapkan Pemkab Tabalong yaitu 13,26 Ha.

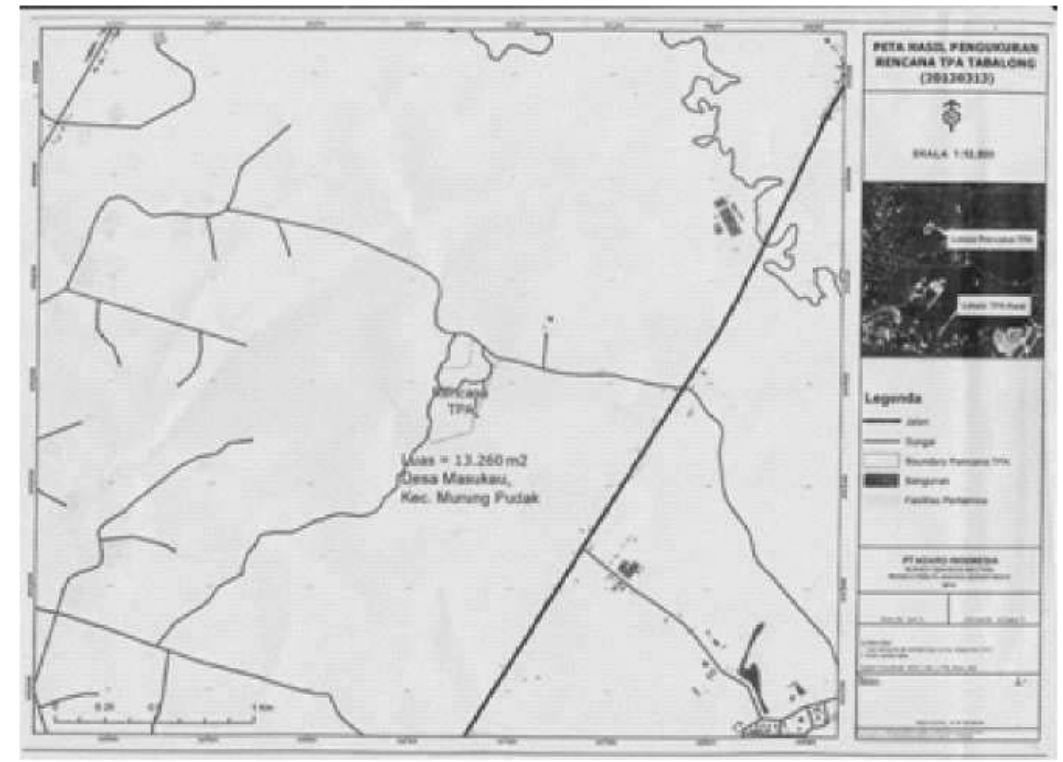

Gambar 1. Rencana Lokasi Pembangunan TPA Masukau Sumber : Dinas Tata Kota dan Kebersihan Kab.Tabalong 2012

\section{Jumlah Penduduk}

Sampah yang akan masuk ke TPA Masukau merupakan sampah yang berasal dari 8 kecamatan. Dalam menentukan volume sampah yang masuk ke TPA akan digunakan jumlah penduduk sebagai dasar analisa timbulan sampah
Dari data Badan Pusat Statistik (BPS) Kabupaten Tabalong, diperoleh data jumlah penduduk yang dapat dilihat pada table 1 : 
Tabel 1. Data Jumlah Penduduk Kab.Tabalong di delapan kecamatan

\begin{tabular}{|c|c|c|c|c|c|c|c|c|c|}
\hline \multirow{2}{*}{ No } & \multirow{2}{*}{ Kecamatan } & \multicolumn{8}{|c|}{ Tahun } \\
\hline & & 2004 & 2005 & 2006 & 2007 & 2008 & 2009 & 2010 & 2011 \\
\hline 1 & Tanta & 14.218 & 14.284 & 14.442 & 14.568 & 15.301 & 16.612 & 17.204 & 17.686 \\
\hline 2 & Tanjung & 27.725 & 27.913 & 28.004 & 28.327 & 29.486 & 30.437 & 32.440 & 33.237 \\
\hline 3 & Murung Pudak & 30.697 & 31.153 & 31.318 & 32.125 & 33.314 & 39.222 & 44.688 & 47.370 \\
\hline 4 & Haruai & 19.251 & 19.355 & 19.374 & 19.476 & 20.127 & 20.522 & 20.416 & 20.710 \\
\hline 5 & Bintang Ara & 6.738 & 6.756 & 7.409 & 7.501 & 7.903 & 8.011 & 7.935 & 7.958 \\
\hline 6 & Upau & 5.967 & 5.995 & 6.037 & 6.267 & 6.749 & 6.822 & 7.046 & 7.205 \\
\hline 7 & Muara Uya & 19.180 & 19.348 & 19.590 & 19.677 & 29.292 & 20.505 & 21.689 & 22.053 \\
\hline 8 & Jaro & 12.462 & 12.517 & 12.579 & 12.623 & 12.718 & 13.547 & 14.197 & 14.512 \\
\hline & Jumlah & 136.238 & 137.321 & 138.753 & 140.564 & 145.590 & 155.678 & 165.615 & 170.731 \\
\hline
\end{tabular}

Sumber : Badan Pusat Statistik Kab.Tabalong (2011)

\section{Tahapan Studi Perencanaan}

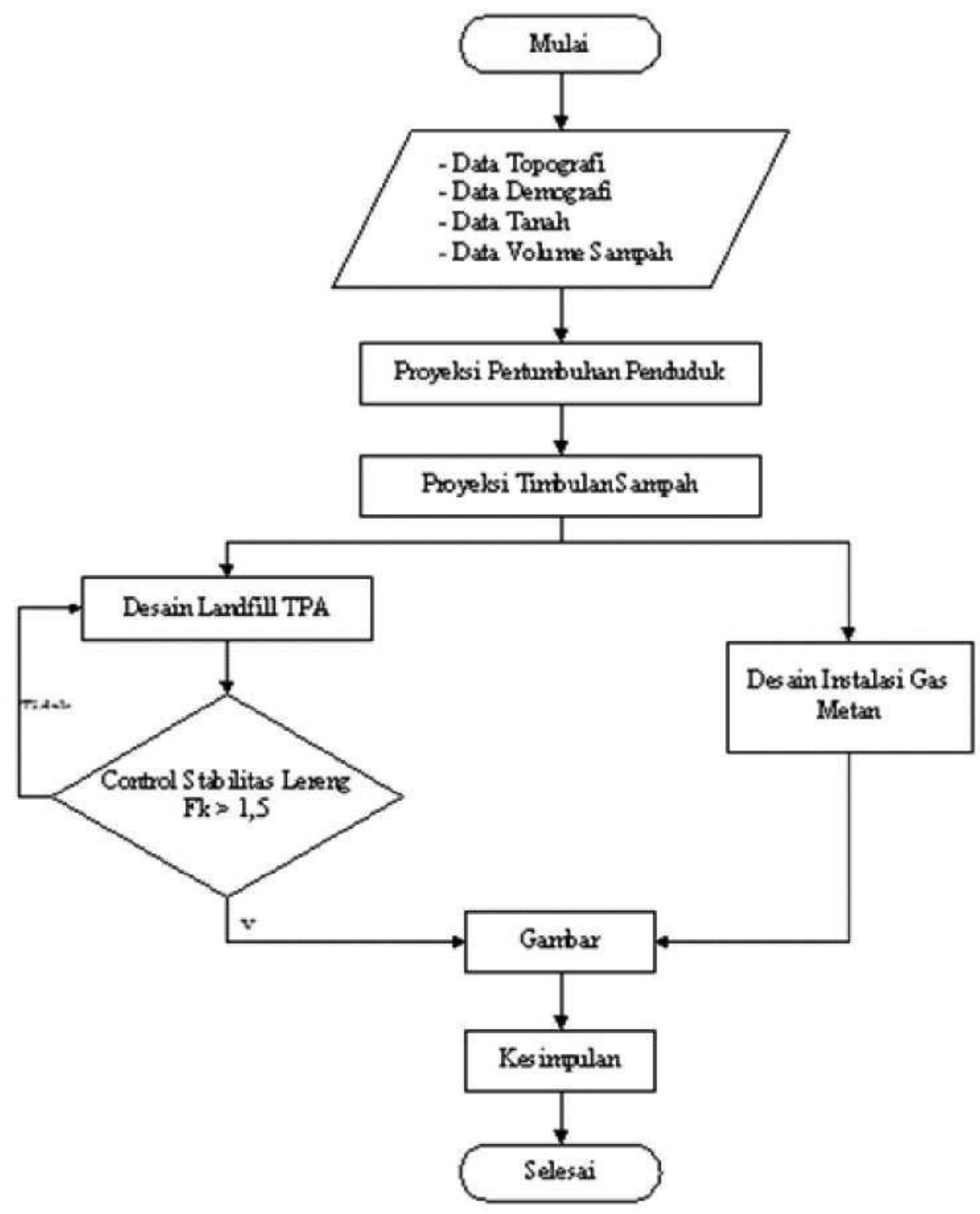

Gambar 2. Tahapan Studi Perencanaan 


\section{HASIL DAN PEMBAHASAN}

\section{Proyeksi Jumlah Penduduk}

Menurut Klosterman, 1990 untuk proyeksi jumlah penduduk ada tiga metode yang sering digunakan yaitu :Metode Aritmatik, Metode Geometrik, dan Metode Least Square. Sebelum penentuan terhadap metode mana yang akan digunakan, dilakukan perhitungan nilai korelasi menggunakan ketiga metode yang telah disebutkan di atas. Metode yang menghasilkan nilai koefisien korelasi mendekati 1 adalah yang akan dipilih untuk menghitung proyeksi penduduk. Menurut Smith, Tayman dan Swanson (2001), Perhitungan nilai koefisien korelasi untuk masing-masing metode dimana digunakan Persamaan :

$r=\sqrt{\frac{D t^{2}-D^{2}}{D t^{2}}}$

Dimana :

$\mathrm{r}=$ koefisien korelasi

$D_{t}^{2}=\sum_{i_{\bar{n} 1}^{1}}^{n}\left(y_{i}-\bar{y}\right)^{2}$
$D^{2}=\sum_{i=1}^{n}\left(y_{i}-g(x)\right)^{2}$
Dari ketiga perhitungan di atas diketahui bahwa Metode Geometri memiliki nilai koefisien yang paling mendekati satu, sehingga metode ini yang akan digunakan untuk memproyeksi jumlah penduduk. Dari jumlah hasil proyeksi penduduk Kabupaten Tabalong 8 Kecamatan diperoleh jumlah penduduk di tahun 2032 yaitu 337.613 jiwa.

\section{Proyeksi Timbulan Sampah}

Berdasarkan hasil perhitungan analisa timbulan sampah di lapangan untuk kabupaten Tabalong adalah $0,22 \mathrm{~kg} /$ org/hari.

Contoh perhitungan timbulan sampah untuk kecamatan Tanta tahun 2011 ialah sebagai berikut:

Timbulan sampah 2011

$=0,22 \times$ Jumlah penduduk 2011

$=0,22 \mathrm{~kg} / \mathrm{org} / \mathrm{hr} \times 17.686$ org

$=3890,92 \mathrm{~kg} / \mathrm{hr}=19,45 \mathrm{~m}^{3} / \mathrm{hr}$

Hasil pengamatan terhadap volume sampah yang masuk ke TPA Masukau untuk tahun 2011 dapat dilihat pada Tabel berikut :

Tabel 2. Prediksi volume sampah /orang/hari

\begin{tabular}{lccccc}
\hline No & Kecamatan & $\begin{array}{c}\text { jumlah penduduk } \\
\text { (org) }\end{array}$ & $\begin{array}{c}\text { Jumlah sampah } \\
(\mathrm{kg} / \text { orang/hari })\end{array}$ & $\begin{array}{c}\text { jumlah sampah } \\
(\mathrm{kg} / \mathrm{hari})\end{array}$ & $\begin{array}{c}\text { vol sampah } \\
(\mathrm{m} 3 / \mathrm{hari})\end{array}$ \\
\hline 1 & 17.686 & 0,22 & 3890,92 & 19,45 \\
2 & Tanta & 33.237 & 0,22 & 7312,14 & 36,56 \\
3 & Murung Pudak & 47.370 & 0,22 & 10421,4 & 52,11 \\
4 & Haruai & 20.710 & 0,22 & 4556,2 & 22,78 \\
5 & Bintang Ara & 7.958 & 0,22 & 1750,76 & 8,75 \\
6 & Upau & 7.205 & 0,22 & 1585,1 & 7,93 \\
7 & Muara Uya & 22.053 & 0,22 & 4851,66 & 24,26 \\
8 & Jaro & 14.512 & 0,22 & 3192,64 & 15,96 \\
\hline
\end{tabular}

Perkiraan timbulan sampah merupakan langkah awal yang biasa dilakukan dalam pengelolaan persampahan. Satuan timbulan sampah ini biasanya dinyatakan dalam satuan kuantitas per orang atau per unit bangunan dan sebagainya. Menurut Litbang Pekerjaan Umum berat jenis sampah adalah $200-$
$350 \mathrm{~kg} / \mathrm{m}^{3}$, untuk perencanaan ini digunakan $200 \mathrm{~kg} /$ $\mathrm{m}^{3}$ berdasarkan perbandingan nilai koefisien yang ditentukan SNI 19-2454-2002.

Contoh perhitungan :

Volume timbulan $(2011)=\quad 187,80 \mathrm{~m}^{3} /$ hari

Berat jenis $=200 \mathrm{~kg} / \mathrm{m}^{3}$ 


$$
\begin{aligned}
\text { Berat timbulan } & =200 \times 187,80=37560 \mathrm{~kg} / \mathrm{hari} \\
& =37,560 \text { ton } / \text { hari }
\end{aligned}
$$

Sampah yang akan ditimbun pada landfill akan dipadatkan untuk menggurangi penggunaan lahan. Sampah akan dipadatkan hingga densitasnya meningkat menjadi $600 \mathrm{~kg} / \mathrm{m}^{3}$ (Damanhuri, 1995). Maka :

$$
\text { Factor kompaksi } \begin{aligned}
(\mathrm{k}) & =\frac{\text { Densitas sampah lepas }}{\text { Densitas sampah terkompaksi }} \\
& =\frac{200 \mathrm{~kg} / \mathrm{m3}}{600 \mathrm{~kg} / \mathrm{ms}}=0,33
\end{aligned}
$$

Volume sampah terkompaksi

$=$ volume sampah $\mathrm{x} \mathrm{k}$

$=37,560 \mathrm{ton} / \mathrm{hr} \times 0,33$

$=12,39$ ton $/$ hari

Selanjutnya dengan cara yang sama, dapat dihitung timbulan sampah hingga dua puluh tahun kedepan.

\section{Rencana Desain Perencanaan}

\section{Desain area penimbunan}

Air tanah di lokasi rencana TPA cukup dalam, sehingga dalam perencanaan ini dipilih penimbunan sampah dengan Metode Trench. Pada lahan tersebut tidak seluruhnya digunakan sebagai area penimbunan mengingat Undang-Undang No.26 Tahun 2007 tentang Penataan Ruang yang menetapkan harus memuat rencana penyediaan dan pemanfaatan ruang terbuka hijau (RTH) yang luasnya minimal $30 \%$ dari total luas lahan. Ada beberapa bagian lahan yang sengaja dikosongkan dengan tujuan untuk menyediakan tempat penampungan lindi, jalan sebagai akses keluar masuk menuju area penimbunan, kantor, parkir, dan lain sebagainya. Masing-masing blok dirancang memiliki 4 lift (tingkat) dimana 1 lift memiliki beberapa sel. Desain sel penimbunan sampah tiap sel adalah sebagai berikut :

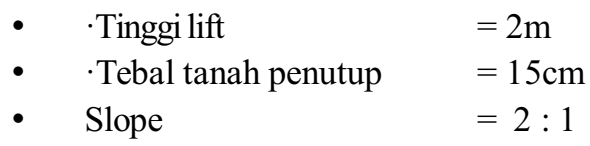

Lapisan dasar yang digunakan dalam landfill direncanakan terdiri dari 5 lapis, yaitu (berurutan dari bawah) :

- Lapisan kedap, merupakan lapisan terbawah yang berfungsi sebagai penahan resapan lindi ke lapisan tanah di bawahnya.

- Menggunakan tanah jenis lempung (clay) dengan koefisien permeabilitas maksimum $1 \times 10^{-7} \mathrm{~cm} /$ detik.

- Ketebalan lapisan ini minimal 60cm.

- Untuk memudahkan penangkapan dan penyaluran lindi, dibuat slope $2 \%$ menuju pipa penangkap lindi.

- Lapisan geomembran bahan HDPE dengan ketebalan minimum $2 \mathrm{~mm}$.

- Lapisan drainase berfugsi sebagai tempat pengaliran lindi menuju ke saluran pengumpul.

- Memiliki koefisien permeabilitas antara 10 ${ }^{2}$ sampai $10^{-1} \mathrm{~cm} /$ detik.

- Menggunakan kerikil dengan ukuran minimum $30 \mathrm{~mm}$.

- Tebal lapisan ini minimum $30 \mathrm{~cm}$ atau 2 kali diameter pipa.

- Lapisan geotekstil, untuk memisahkan pasir di atasnya dengan kerikil di bawahnya (minimal dapat menyaring butiran)

- Lapisan tanah pelindung berupa pasir dengan ketebalan $30 \mathrm{~cm}$.

\section{Rencana Sel}

Dari sampah yang masuk ke area penimbunan maka akan dibuat beberapa sel, berikut rencana perletakan sel :

- Sampah yang masuk ditumpuk untuk membentuk sel sampah

- Sampah yang masuk ke lahan urug akan diratakan dan dipadatkan secara bertahap setiap $50 \mathrm{~cm}$, hingga mencapai ketinggian $2 \mathrm{~m}$, kemudian sampah ditutup dengan menggunakan tanah dan dipadatkan hingga setebal $15 \mathrm{~cm}$.

- Tanah penutup antara menggunakan tanah urug.

- Bentuk sel menyesuaikan bentuk lahan area penimbunan 
Tabel 3. Kapasitas Tampung Landfill

\begin{tabular}{ccccccc}
\hline \multirow{2}{*}{ No } & \multirow{2}{*}{ lift } & tinggi & \multirow{2}{*}{ slope } & \multicolumn{2}{c}{ luas $\left(\mathrm{m}^{2}\right)$} & \multirow{2}{*}{ volume $\left(\mathrm{m}^{3}\right)$} \\
\cline { 5 - 6 } & & lift $(\mathrm{m})$ & & atas & Bawah & \\
\hline 1 & 1 & 2,15 & $1: 1$ & 45054,70 & 45054,70 & 96867,61 \\
2 & 2 & 2,15 & $1: 1$ & 45054,70 & 45054,70 & 96867,61 \\
3 & 3 & 2,15 & $1: 2$ & 41127,61 & 45054,70 & 92613,91 \\
4 & 4 & 2,15 & $1: 2$ & 38626,36 & 40348,68 & 84891,44 \\
5 & 5 & 2,15 & $1: 2$ & 35425,13 & 37942,67 & 78854,90 \\
6 & 6 & 2,15 & $1: 2$ & 32523,91 & 34836,68 & 72398,40 \\
7 & 7 & 2,15 & $1: 2$ & 29922,71 & 31030,71 & 65521,32 \\
8 & 8 & 2,15 & $1: 2$ & 26621,53 & 28524,76 & 59270,49 \\
9 & 9 & 2,15 & $1: 2$ & 23648,48 & 25319,3 & 52630,15 \\
\hline
\end{tabular}

Sel landfill direncanakan sebanyak 1 zona, yang artinya total volume sampah yang bisa ditampung adalah $699.915,81 \mathrm{~m}^{3}$. Sedangkan volume timbulan sampah untuk 20 tahun mendatang di TPA Masukau sebesar $668.760,08 \mathrm{~m}^{3}$. jadi dapat disimpulkan desain Sel dapat menampung sampah untuk 20 tahun ke depan. $699.915,81 \mathrm{~m}^{3}>668.760,08 \mathrm{~m}^{3}$....ok!!

\section{Kontrol Stabilitas Lereng}

\section{Analisis Stabilitas Lereng dengan Software Slide}

Untuk mengontrol stabilitas lereng yang ada di TPAMasukau diperlukan data tanah sebagai berikut

\begin{tabular}{ccc}
\multicolumn{4}{c}{ Tabel 4. } & Data Tanah TPA Masukau \\
\hline Data & Sampah & Tanah \\
\hline C & $0,2 \mathrm{~kg} / \mathrm{cm}^{2}$ & $0,29 \mathrm{~kg} / \mathrm{cm}^{2}$ \\
$\square$ & $0.8 \mathrm{t} / \mathrm{m}^{3}$ & $1,75 \mathrm{t} / \mathrm{m}^{3}$ \\
$\varnothing$ & $20^{\circ}$ & $13,39^{\circ}$ \\
\hline
\end{tabular}

Sumber : Uji Lab

Dalam praktiknya, untuk memperoleh angka keamanan yang paling minimum dengan meletakkan titik pusat bidang longsor, maka kita dapat melakukan coba-coba penempatan pusat bidang longsor dengan jangkauan tertentu. Untuk mempermudahnya, bisa digunakan software Slide . Dengan menggunakan program ini, dapat dengan mudah dan cepat memperkirakan letak pusat bidang longsor yang paling aman.

Langkah analisis stabilitas menggunakan Slide adalah sebagai berikut :

- Import file gambar sel dari Autocad dengan format .dxf.

- Gambar sel dengan menggunakan tool Draws.
Beri keterangan masing-masing untuk tanah dan sampah melalui properties - Define Material.

- Pada input nama isi dengan tanah, pada keterangan strenght type pilih dengan Mohr Coloumb, beri warna yang berbeda untuk setiap jenis material.

- Pada keterangan Strenght Parameter isikan data sudut geser $\left({ }^{\circ}\right)$, kohesi $\left(\mathrm{kN} / \mathrm{m}^{2}\right)$, dan berat jenis material $\left(\mathrm{kN} / \mathrm{m}^{3}\right)$ pada masingmasing timbunan.

- Kemudian kita lakukan identifikasi metode dan parameter perhitungan. Langkah pertama untuk menentukan metode perhitungan adalah klik menu Analysis - Project Settings.

- $\quad$ Pada menu Method, kita bisa memilih metode yang dipakai, dalam hal ini adalah Bishop, Ordinary dan Janbu.

- Menentukan titik pusat bidang longsor, yakni dengan menggunakan tool Auto Grid sehingga Rocscience Slide akan membuat sebuah kotak dengan kemungkinan bidang longsor.

- Bila akan menganalisis stabilitas lereng pada keadaan gempa, maka nilai koefisien gempa pada lokasi rencana tersebut dimasukkan pada Loading - Seismic Load.

- Langkah terakhir adalah Analysis - Compute, komputer akan mendeteksi angka - angka keamanan berdasarkan data dan kondisi yang telah ada. Angka yang muncul merupakan nilai $F S$ terkecil. Dalam perencanaan stabilitas lereng, nilai ini memenuhi apabila $F S>1,5$ pada keadaan normal dan FS $>1,1$ pada keadaan gempa.

Setelah proses Compute, dapat diketahui nilai angka keamanan minimum dan gambar bidang longsornya pada menu Analysis - Interpret . 


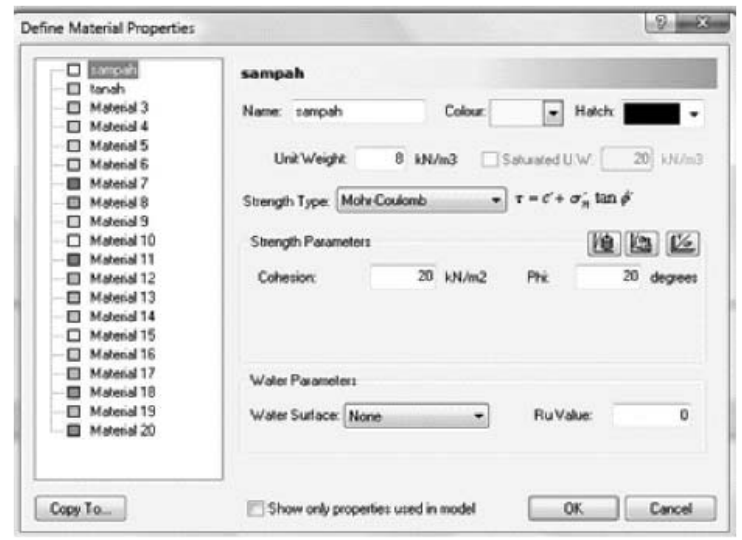

Gambar 3. Menentukan jenis dan parameter material timbunan

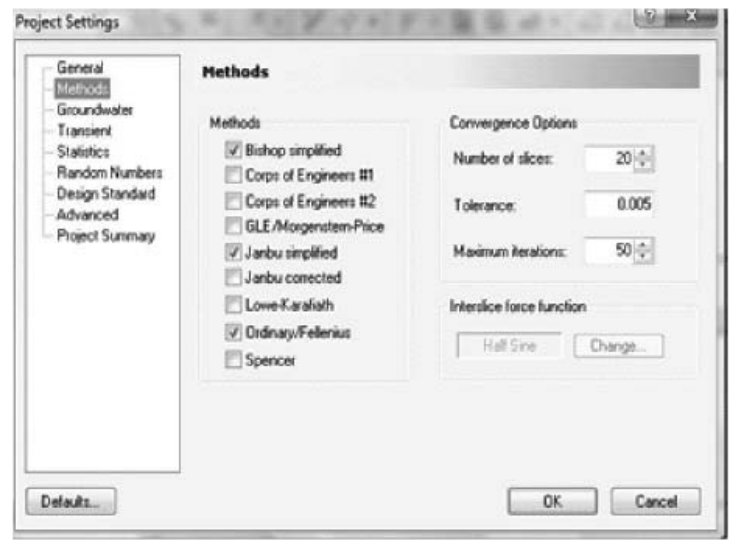

Gambar 4. Identifikasi Metode dan Parameter Perhitungan

Dalam analisis menggunakan software Rocscience Slide 6.005 ini diperoleh angka-angka keamanan Timbunan sampah terhadap kelongsoran melalui beberapa metode (Bishop , Fellenius dan $J a n b u)$ sebagai berikut:

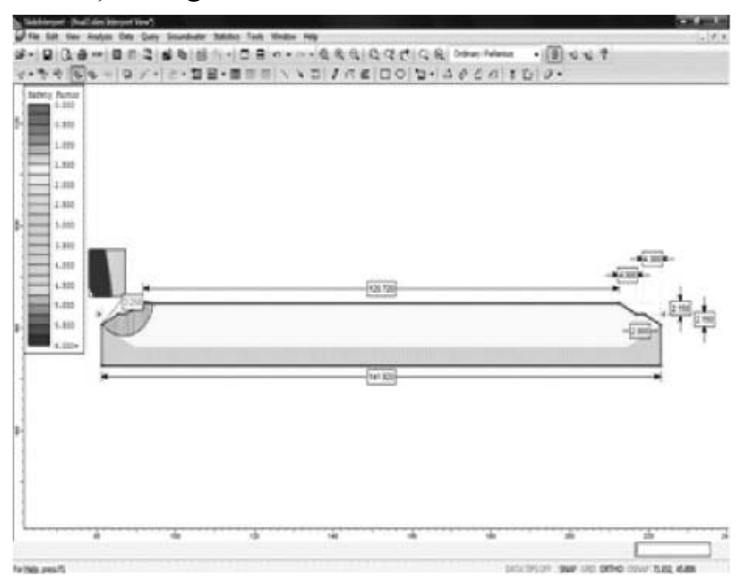

Gambar 5. Output yang dihasilkan adalah nilai $F S_{\text {min }}$ dan gambar bidang longsor
Tabel 5. Analisis stabilitas lereng TPA Masukau menggunakan Slide

\begin{tabular}{ccc}
\hline No & Metode & $\boldsymbol{F s}$ \\
\hline 1 & Bishop & 4,322 \\
2 & Fellenius & 4,019 \\
3 & Janbu & 3,814 \\
\hline
\end{tabular}

Sumber : Hasil Perhitungan

Dengan demikian angka keamanan minimum stabilitas lereng yang diperoleh dari software Slide ini, diperoleh angka-angka keamanan timbunan sampah dengan Fs $>1,5$ pada keadaan normal sehingga dinyatakan aman terhadap kelongsoran.

\section{Pengelolaan Gas}

Seperti penjelasan sebelumnya, proses dekomposisi bahan organik dalam sampah akan menghasilkan gas dan panas. Komposisi gas terbesar yang dihasilkan dalam landfill adalah gas karbondioksida dan gas metana. Kedua jenis gas ini termasuk dalam jenis gas yang dapat menyebabkan efek greenhouse pada lingkungan. Bahkan jika konsentrasi metana mencapai $10-15 \%$ di udara bebas, maka gas ini dapat menyebabkan ledakan.

Gas $\mathrm{CH}_{4}$ yang dihasilkan dapat digunakan sebagai bahan bakar. Namun bila tidak terdapat fasilitas untuk mengambil gas ini, cukup dibuat pipa ventilasi agar tidak terjadi akumulasi gas di dalam landfill dengan pengontrolan berkala.

\section{Sistem Pengumpulan dan Penangkapan Gas di Lahan TPA}

Tchobanoglous, Theisen, dan Vigil (1993), menuliskan dua cara untuk menangkap gas pada landfill, yaitu dengan cara aktif dan pasif. Aktif yaitu terdiri dari blower mekanik atau kompressor yang tergabung dalam sistem ekstraksi sumur gas atau parit pengumpul dan tersedia instalasi untuk pengolahan lanjutan gas. Gradien tekanan dibuat dalam sumur atau parit, dan kemudian memaksa keluarnya gas dari lahan TPA. sedang Pasif hanya menggunakan pipa untuk ventilasi. Berikutnya akan dijelaskan cara pasif karena metode ini yang akan digunakan. Pemasangan pipa untuk control gas dari dalam landfill dilakukan secara vertikal dan horizontal. 


\section{Pemasangan pipa pengumpul gas secara vertikal.}

Pendekatan yang pertama adalah instalasi sumur-sumur vertikal. ${ }_{<0\}\{0>}$ After an entire landfill has reached its final height, boreholes will be drilled and HDPE piping and a permeable medium (gravel, rock) is installed (figure 21.4) ${ }_{<\} 92\{>}$ Setelah landfill keseluruhan mencapai ketinggian akhirnya, maka lubang-lubang akan dibor kemudian dipasang pipapipa menangkap gas. Dalam perencanaan ini, jarak antar pipa adalah $24 \mathrm{~m}$, kedalaman penanaman pipa minimal $75 \%$ dari kedalaman total landfill (Tchobanoglous, Theisin, dan Vigil, 1993). Pipa ventilasi gas berdiameter $15 \mathrm{~cm}$ dipasang dengan membuat lubang berdiameter $60 \mathrm{~cm}$. Pipa yang digunakan memiliki lubang perforasi diameter $1 \mathrm{~cm}$ hingga ketinggian lapisan penutup. Di sekeliling pipa diberi kerikil ukuran $2 \mathrm{~cm}$.

${ }_{\{0>}$ This approach must have a proper design and some precautions should be kept in mind. ${ }_{<\} 100\{>}$ Perencanaan ini harus memiliki desain yang tepat dan harus sangat hati-hati. ${ }_{<0\}}\{0>$ When gas wells are connected the a flare installation too early leachate might clog the piping of the gas well and the system might be ineffective. ${ }_{<\} 100\{>}$ Ketika sumur-sumur gas dikoneksikan ke instalasi flare terlalu awal, maka kemungkinan yang terjadi adalah bahwa lindi awal bisa menyumbat pipa sumur gas dan sistem tersebut tentu menjadi tidak efektif. ${ }_{<0}$ \} ${ }_{\{0>}$ It is save if the first connection is made around $1,5-2 \mathrm{~m}$. above the groundwater table. ${ }_{<>79\{>}$ Sistem ini bisa menjadi sistem yang aman dan baik ketika koneksi pertama dilakukan sekitar 1,5 - $2 \mathrm{~m}_{<0 \text { \} }}$ ${ }_{\{0>}$ Furthermore the gas extracted in the beginning of the exploitation phase has poor quality ${ }_{<\} 100<>}$ Sementara itu, gas yang diekstraksi pada awal fase eksploitasi memiliki kualitas yang buruk. ${ }_{<0}$ \} ${ }_{\{0>}$ Poor quality landfill gas can be oxidised by more sophisticated flare installations, but these types of flares are more expensive also. ${ }_{<\} 100\{>}$ Gas landfill yang memiliki kualitas buruk dapat dioksidasi dengan instalasi flare yang lebih baik, namun tipe-tipe flare ini juga lebih mahal.

\section{Pemasangan pipa pengumpul gas secara horizontal}

Model peletakan pipa dengan metode ini, adalah dengan cara menyusun pipa pengumpul gas secara berbaris. Pada pemasangannya perlu juga dilengkapi dengan pipa-pipa pengontrol bau. Peletakan pipa pengumpul gas secara horizontal ini dilakukan setelah dua atau lebih lift sampah terisi. Pipa diletakan di antara tumpukan sampah yang di buat. Sampah di gali dengan kedalaman tertentu, kemudian diisi dengan kerikil, sebelum akhirnya pipa beroperasi ditanam didalamnya.

\section{KESIMPULAN DAN SARAN}

\section{Kesimpulan}

Kesimpulan dari perencanaan ini adalah sebagai berikut:

- Dari analisa pertumbuhan penduduk dan timbulan sampah dengan menggunakan metode geometri untuk proyeksi 20 tahun mendatang didapatkan jumlah penduduk tahun 2032 sebesar 5.394.643 jiwa dan timbulan sampah sebesar 668.760,08 $\mathrm{m}^{3}$. Dari perhitungan perencanaan landfill didapatkan volume sampah yang mampu ditampung TPA Masukau sebanyak 699.915,81 $\mathrm{m}^{3}$ dengan luas 4,51 ha. Dari umur rencana TPA selama 20 tahun akan terkumpul sampah sebanyak $668.760,08 \mathrm{~m}^{3}$, sehingga desain rencana cell TPA Masukau memenuhi syarat kelayakan. $699.915,81 \mathrm{~m}^{3}>668.760,08 \mathrm{~m}^{3}$. Ok!!!

- Dalam perencanaan ini, jarak antar pipa adalah $30 \mathrm{~m}$, kedalaman penanaman pipa $75 \%$ dari kedalaman total landfill. Pipa ventilasi gas berdiameter $15 \mathrm{~cm}$ dipasang dengan membuat lubang berdiameter $45 \mathrm{~cm}$. Pipa yang digunakan memiliki lubang perforasi diameter $1 \mathrm{~cm}$ hingga ketinggian lapisan penutup. Di sekeliling pipa diberi kerikil ukuran $2 \mathrm{~cm}$. Jumlah pipa pengkap gas yang direncanakan berjumlah 48 buah.

- Dari analisa stabilitas lereng timbulan sampah didapatkan nilai FS dengan menggunakan metode Bishop $=4,322$, Fellenius $=4,019$, dan metode Janbu $=3,814$, dimana semua nilai tersebut lebih besar dari angka faktor keamanan 1,5 sehingga dinyatakan aman.

\section{Saran}

- $\quad$ Perlu adanya perhitungan untuk mengetahui kondisi dan kualitas sampah yang akan 
ditimbun, apabila memungkinkan dapat dilakukan analisa untuk pengurangan sampah yang masuk ke TPA.

- Perencanaan Sanitary Landfill pada lahan rencana TPAMasukau ini perlu ditindak lanjuti dengan perencanaan DED (Detail Engineering Design) dan rincian biaya yang dibutuhkan.

- Hendaknya area rencana TPA berada jauh dari sungai minimal 500m, berdasarkan Konsep Pedoman Pemanfaatan Ruang Kawasan Sekitar TPA Sampah, Direktur Penataan Ruang Nasional.

\section{DAFTAR PUSTAKA}

Badan Pusat Statistik. 2012. Kabupaten Tabalong Dalam Angka Tahun 2011. BPS Kabupaten Tabalong, Kalimantan Selatan

Damanhuri, Enri. 1995. Diktat Kuliah TL - 453: Teknik Pembuangan Akhir. Bandung : Jurusan Teknik Lingkungan Fakultas Teknik Sipil dan Perencanaan Institut Teknologi Bandung (ITB).

Das, Braja M. 1993. Mekanika Tanah (Prinsipprinsip Rekayasa Geoteknis) Jilid 2. Penerbit Erlangga, Jakarta.

Klosterman, Richard E. 1990. "Community Analysis and Planning Techniques". Savage, Rowman \& littlefield.

Smith, Stanley, Jeff, Tayman, and David, Swanson. 2001. State and Local Population Projections : Methodology and Analysis. New York. Kluwer Academic/Plenum Publishers.

SNI 19-2454-2002, "Tata Cara Teknis Operasional Pengelolaan Sampah Perkotaan". DPU

Tchobanoglous, G., Theisen, H., dan Vigil, S. 1993. "Integrated Solid Waste Management : Engineering Principles And Management Issues". New York : Mc Graw-Hill International Editions.

Undang-Undang Republik Indonesia No. 18 Tahun 2008. "Tentang Pengelolaan Sampah". Direktorat Jendral Peraturan Perundangundangan. Jakarta.

Undang-Undang Republik Indonesia No. 26 Tahun 2007, “Tentang Penataan Ruang”. Direktorat Jendral Peraturan Perundangundangan. Jakarta.
Pichtel, J. 2005. "Waste, Its Origin, Its Destination". CRC Press, Amerika Serikat. 